Louisiana State University

LSU Digital Commons

Faculty Publications

Department of Oceanography \& Coastal

Sciences

$11-1988$

\title{
Modeling Wetland Loss in Coastal Louisiana: Geology, Geography, and Human Modifications
}

James H. Cowan Jr.

R. Eugene Turner

euturne@lsu.edu

Follow this and additional works at: https://digitalcommons.Isu.edu/oceanography_coastal_pubs

\section{Recommended Citation}

Cowan, J. H., \& Turner, R. (1988). Modeling Wetland Loss in Coastal Louisiana: Geology, Geography, and Human Modifications. Environmental Management, 12 (6), 827-839. Retrieved from

https://digitalcommons.Isu.edu/oceanography_coastal_pubs/160

This Article is brought to you for free and open access by the Department of Oceanography \& Coastal Sciences at LSU Digital Commons. It has been accepted for inclusion in Faculty Publications by an authorized administrator of LSU Digital Commons. For more information, please contact ir@lsu.edu. 


\section{Modeling Wetland Loss in Coastal Louisiana: Geology, Geography, and Human Modifications}

\author{
JAMES H. COWAN, JR.* \\ R. EUGENE TURNER \\ Coastal Ecology Institute \\ Center for Wetland Resources \\ Louisiana State University \\ Baton Rouge, Louisiana, 70803-7507 USA
}

ABSTRACT / Habitat change in coastal Louisiana from 1955/6 to 1978 was analyzed to determine the influence of geological and man-made changes on landscape patterns within $7.5 \mathrm{~min}$ quadrangle maps. Three quantitative analyses were used: principal components anlaysis, multiple regression analysis, and cluster analysis.

Regional differences in land loss rates reflect variations in geology and the deltaic growth/decay cycles, man-induced chages in hydrology (principally canal dredging and spoil banking), and land-use changes (principally urbanization and agricultural expansion). The coaștal zone is not homogeneous with respect to these variables and the interaction between causal factors leading to wetland loss is therefore locally variable and complex.

The relationship between wetland loss, hydrologic changes, and geology can be described with statistically meaningful results, even though these data are insufficient to precisely quantify the relationship. However, these data support the hypothesis that the indirect impacts of man-induced changes (hydrologic and land use) may be as influential as the direct impacts resulting in converting wetlands to open water (canals) or modified (impounded) habitat.

Three regions within the Louisiana coastal zone can be defined, based on the potential causal factors used in the analyses. The moderate (mean $=22 \%$ ) wetland loss rates in region 1 are a result of relatively high canal density and developed area in marshes which overlie sediments of moderate age and depth; local geology acts, in this case, to lessen indirect impacts. On the other hand, wetland loss rates in region 2 are high (mean $=36 \%$ ), despite fewer man-induced impacts; the potential for increased wetland loss due to both direct and indirect effects of man's activity in these areas is high. Conversely, wetland loss (mean = $20 \%$ ) in region 3 is apparently least influenced by man's activity in the coastal zone because of sedimentary geology (old, thin sediments), even though these areas have already experienced significant direct habitat alteration and wetland loss.
Louisiana's coastal wetland loss rate $\left(>100 \mathrm{~km}^{2}\right.$ $\mathrm{yr}^{-1} ; 0.8 \%$ of total annually; Gagliano and others 1981 ) is a chronic state problem. Some of the implications of this loss include decreased fisheries, economic loss (oil and gas revenues), and increased storm damage (Craig and others 1980). Causes for these losses are complex but have been attributed to both natural and man-induced factors (Scaife and others 1983, Walker and others 1987).

Statistical (quantitative) methods can be used to test hypotheses about the relative importance and interaction of various potential causal factors (natural and man-induced) that are correlated with landscape changes, as well as to understand possible options for resource management and mitigation potential. Man may influence wetland loss in coastal Louisiana through flood control measures, urban and agricul-

KEY WORDS: Wetland loss; Geology; Coast; Models; Louisiana

\footnotetext{
*Author to whom correspondence should be sent: University of Maryland, Center for Environmental and Estuarine Studies, Chesapeake Biological Laboratory, P.O. Box 38, Solomons, MD 20688.
}

tural practices, and canal and spoil bank construction. Natural factors include changes in local geology and hydrology caused by the dynamic nature of Louisiana's sedimentary coastline. Although locally significant influences (causes) tend to be obscured as landscape size increases, analysis on a regional scale is one way to isolate and quantify regionally significant factors.

Unfortunately, few habitat data contain sufficient temporal and spatial resolution on a regional scale to be both useful in a quantitative analysis of land loss and helpful to natural resource managers, particularly for coastal ecosystems. An understanding of the potential causal mechanisms of wetland loss in Louisiana could be enhanced by combining in one analysis those factors previously absent, or only partially included in other studies, that is, quantitative instead of qualitative data (Gagliano 1973, Craig and others 1980, Walker and others 1987), inclusion of the whole coast instead of just selected areas (Scaife and others 1983), and combining geologic factors into the spatial analyses (Deegan and others 1984).

There is one habitat change study of the Louisiana coast, completed for the US Fish and Wildlife Service 


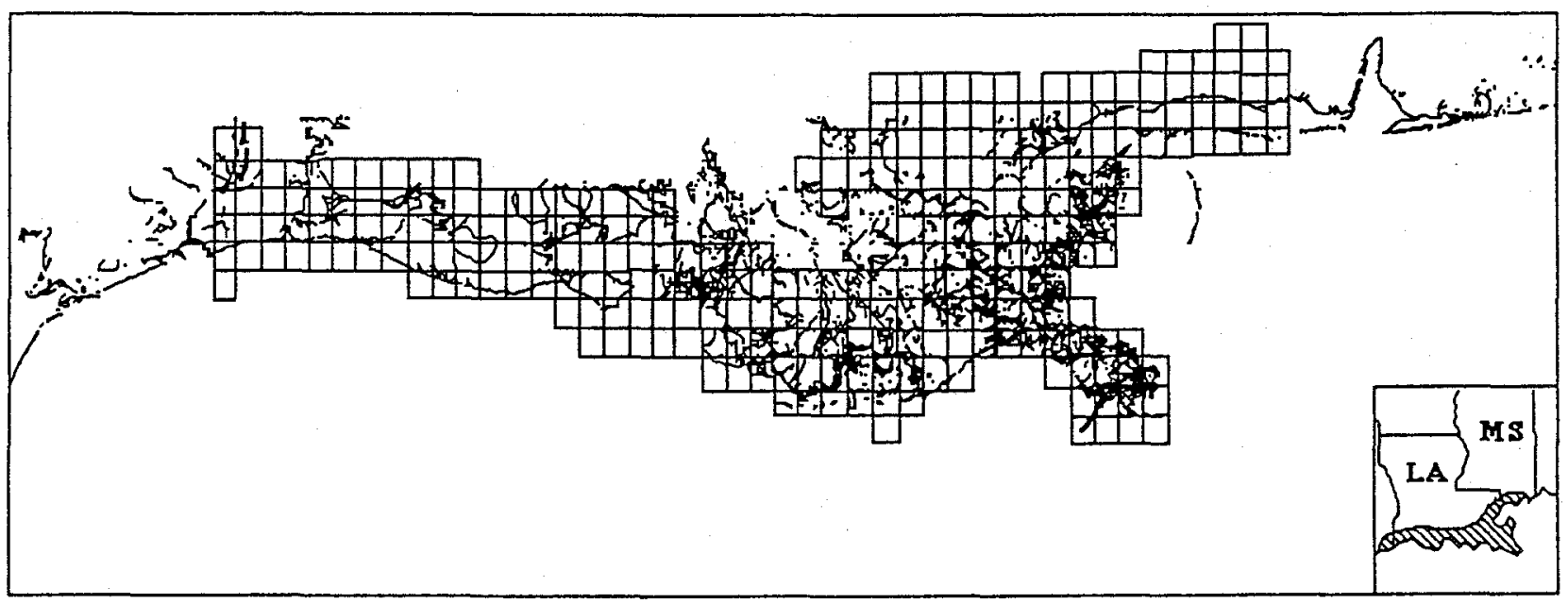

Figure 1. Location of topographic map units interpreted and measured within the study area.

(USFWS) by Wicker $(1980,1981)$ that we believe to have sufficient resolution to allow a quantitative analysis of some of the mechanisms believed to influence land loss. That study determined changes in 200 habitat categories (following the Cowardin and others 1979 classification scheme) from 1955 to 1978 in 464 (232 for 1955; 232 for 1978) 7.5-min topographic quadrangle map units (1:24,000 scale) (Figure 1). Scaife and others (1983) used these data to describe land loss in selected geologic substrates as a function of canal density. In a preliminary analysis of land loss in the Mississippi River Deltaic Plain, Deegan and others (1984) used the habitat data to integrate the regional geologic influences with man-induced factors into one model; for reasons to be discussed below, their analysis was flawed. We report our use of the Louisiana habitat data to quantitatively relate land loss (primarily wetlands in the form of coastal marshes) to both maninduced and natural geologic factors, combined here for the first time into one analysis, that we believe describe (and perhaps predict) habitat change.

\section{The Louisiana Coast: Wetland Loss and Contributing Factors}

The Louisiana coastal zone was formed over the last $7,000 \mathrm{yr}$ by sediments deposited during a series of 16 major Mississippi River deltaic episodes (Frazier 1967, Kosters and others 1987, Walker and others 1987). The landscape now consists of narrow ridges of high ground a meter or so above sea level located along abandoned river distributaries, between which lie vast expanses of low-lying marshes. These wetlands comprise more than $40 \%$ of the coastal wetlands in the conterminous United States and more than $65 \%$ of the marshes surrounding the US Gulf of Mexico (Turner and Gosselink 1975, Deegan and others 1984). These expansive wetlands are rich in renewable resources; Louisiana supports the nation's largest commercial fishery with landings approaching 2 billion pounds in 1986 (US Department of Commerce 1987) and leads the US in fur-bearer harvest (Chabreck 1979). Hunting and recreational fishing contribute $\$ 235$ million annually to the economy of the state (US Department of Interior 1982). Coastal Louisiana is also rich in oil and gas resources and ranked third in crude oil and first in natural gas production in the United States (American Petroleum Institute 1981). Oil and gas activities in these coastal wetlands consist primarily of canal dredging for pipeline construction and drilling site access; construction of major navigation channels has also taken place (Deegan and others 1984). Dredging and its associated activities (e.g., spoil banking) represent significant development pressure on Louisiana's coastal wetlands, and nearly one-third of all US Army Corps of Engineer (COE) permitted dredge and fill activities occur in Louisiana (Mager and Hardy 1986). Consequently, development of oil and gas resources in Louisiana has spurred much habitat alteration in the coastal zone.

Historically, the biological and physical factors which contribute to wetland development or loss have been nearly in balance along the Louisiana coast, resulting in wetland gain and some periodic episodes of localized wetland loss (Cowan and others 1988). Currently, however, the amount of sediments deposited by riverine systems or accumulated by biological processes appears to be less than necessary to match relative sea level rise (subsidence and eustatic sea level rise combined) (Turner 1985, Cowan and others 1988, Ca- 
Table 1. Habitat classifications used to develop land use groups.

\begin{tabular}{ll}
\hline Land use category & Habitat classification (based on Costanza and others 1983) \\
\hline Marsh & Brackish marsh, fresh marsh, salt marsh \\
Swamp & Bottomland hardwood, cypress-tupelo swamp, mangrove \\
Forest/upland & Fresh shrub-scrub, upland forest \\
Aquatic grass bed/mudflat & Fresh aquatic bed, estuarine aquatic bed, mudflat \\
Canal and spoil & Canal, spoil \\
Open water & Fresh open water, estuarine open water \\
Urban/agriculture & Agriculture, urban/industrial \\
Beaches and dunes & Beaches, sand dunes \\
\hline
\end{tabular}

hoon and Cowan 1987). Virtually all of the land loss in Louisiana occurs as wetland loss, which is a complex process influenced directly and indirectly by natural and man-induced activities. The term wetland loss refers to the conversion of wetland habitat type to either open water or upland habitat (spoil bank, agriculture, or urbanized; Cahoon and Cowan 1987, Cahoon and others 1986). Land loss can result from a variety of interrelated causes: (a) natural and man-induced erosion of shoreline or the banks of waterways and canals; (b) dredging and filling of marshes by man, primarily associated with the oil and gas extraction industry; and (c) submergence of interior marshes. Submergence occurs when natural land building or maintenance processes (sedimentation and accumulation of plant matter) lag behind geologically mediated rise of relative sea level (subsidence, compaction, consolidation, etc.) Sediment compaction rates of deltaic deposits depend on the age and location within the delta lobe, the amount and type of sediment input, and the depth of sediment overlying the downwarped Pleistocene terrace (Kolb and Van Lopik 1958, Morgan 1963, Walker and others 1987). In general, sediment compaction in Louisiana's coastal wetlands decreases as the distance from the coast increases (Kolb and Van Lopik 1958, Deegan and others 1984). Sediment input and organic accumulation counteracts compaction and contributes to land accretion. Sediment input to marshes is achieved by overbank flooding of rivers (e.g., Mississippi and Atchafalaya), bays, bayous, and other waterways. However, the supply and distribution of sediments are not static in recent time. According to Meade and Parker (1984), suspended sediments in the Mississippi River apparently declined by more than $50 \%$ since the early 1950s. Furthermore, the lower Mississippi River has flood-protection levees which reduce overbank flooding except near the river's lower reaches.

The loss of wetlands by erosion and dredge/fill activities is caused by a direct disruption of the substrate by natural or man-induced mechanical stress (that is, waves, boat wakes, and dredges), resulting in either open water or upland habitat (Cahoon and others 1986). Some of these impacts are immediately apparent, as dredging activities have directly converted 55,000 ha $(\sim 10 \%)$ of Louisiana's coastal wetlands to open water habitat since 1900 (Lindstedt and Nunn 1985). However, canals and their associated spoil banks also restrict or eliminate regular overbank flooding (Davis 1973, Gosselink and others 1979, Craig and others 1980, Turner and others 1982, Turner 1985, Day and others 1986, Cahoon and others 1986, Cahoon and Cowan 1987). This results in an indirect, less readily apparent impact on the submergence of interior marshes. Indirect impacts have been estimated to cause $25-90 \%$ of wetland loss in Louisiana (Turner 1985, for review). Coastal submergence is influenced by these activities because levees (spoil banks) affect the duration and frequency of tidal inundation, which in turn affect sediment and nutrient supply, as well as the availability of oxygen and toxins that may influence plant growth and the deposition of organics (Cahoon and others 1986, Swenson and Turner 1987). This is particularly true for areas that unintentionally become semi-impounded and where no attempt is made to manage the hydrologic regime (Cahoon and others 1986, Cahoon and Cowan 1987, Cowan and others 1988).

\section{Methods}

Data used in this analysis were derived from the Louisiana habitat mapping study of Wicker (1980, 1981). Habitat area in the Louisiana coastal zone in each map unit (7.5-min quadrangle; 1:24,000 scale) were planimetered from images built from aerial photography. Wicker $(1980,1981)$ constructed the images for 1955/56 and 1978 because the entire Louisiana coastal zone was flown and photographed from high altitude during those years.

We combined the 200 habitat types into 8 broad categories (Table 1) following Costanza and others (1983) and restricted our analysis to 166 quadrangle map units. Maps were eliminated from this analysis if: 
Table 2. A summary of the area (ha) of the land use categories in the original Louisiana habitat data (Wicker $1980,1981)$ compared with the area in the analyzed data set.

\begin{tabular}{lrrr}
\hline 1978 Habitat category & $\begin{array}{c}\text { Complete data set } \\
(\mathrm{A})\end{array}$ & $\begin{array}{c}\text { Analyzed data set } \\
(\mathrm{B})\end{array}$ & $\begin{array}{c}\mathrm{B} / \mathrm{A} \times 100 \\
(\%)\end{array}$ \\
\hline Marsh & $1,009,320$ & 827,642 & 82.2 \\
Swamp & 177,078 & 127,496 & 72.0 \\
Forest/upland & 57,550 & 45,465 & 79.1 \\
Aquatic grass bed/mudflat & 26,788 & 16,341 & 61.1 \\
Canal and spoil & 80,426 & 64,904 & 80.7 \\
Open water & $2,162,776$ & $1,641,547$ & 75.9 \\
Urban/agriculture & 211,848 & 169,478 & 80.0 \\
Beaches and dunes & 4,758 & 3,331 & 70.1 \\
Total area all habitats & $3,728,402$ & $2,831,949$ & 76.0 \\
\hline
\end{tabular}

(a) wetlands within the quadrangle were part of an active river delta and receiving significant new sediment deposition (Kosters and others 1987); (b) wetland area within the quadrangle was less than $2.5 \%$ ( $405 \mathrm{ha}$ ) of the total area; or (c) the total measured area in a quadrangle in 1955/56 was not within $0.5 \%$ (80 ha) of the total measured area in the 1978 map. Our reasons for selecting these criteria were to limit the analysis to marshes not undergoing rapid change caused by sediment deposition, and to decrease the proportion and opportunity for error since mapping errors decrease with increased areal coverage of marshes in a map. Several $(\sim 30)$ quadrangle maps were eliminated because they contained large-scale human modifications (that is, changes in the area of urbanization, agriculture or impounded wetlands) that occurred between 1955/56 and 1978; consequently, these appeared as outliers. Data analyzed in this study represent approximately $76 \%$ of the area of the coastal marshes in Louisiana (Table 2).

We chose variables to represent both natural and man-induced factors which we believe to influence marsh loss. Natural factors include coastal morphology and sediment input and age, compaction, and subsidence; man-induced factors are related to development in the coastal zone, e.g., canal dredging, agriculture, and urbanization. Wetland loss is defined as the difference between marsh area in 1955/56 and 1978. A positive number represents loss in marsh area. The initial wetland (marsh) area is given as the total marsh area in the $1955 / 56$ quadrangles. The variable "age" is the estimated age (years) of the subdelta lobe that underlies the coastal marshes (Frazier 1967). Depth is the depth (m) of sediment overlying the Pleistocene terrace (Fisk and McFarlan 1955). The variable distance corresponds to the distance $(\mathrm{m})$ from the center of each quadrangle to the Louisiana coast on 1974 USGS, 1:250,000 maps. The estimates of age and sediment depth are not precise because the Louisiana coast was formed by a series of overlapping deltaic episodes stacked one on top of another. Consequently, the estimated age of the last deltaic episode was used in this analysis, following Deegan and others (1984).

The percentage of marsh lost in a quadrangle map unit was modeled as a function of the area of agriculture and urban development (DEVDENS) in 1978, the area of canals and spoil (CANDENS), the estimated age of sediments (SEDAGE), the depth of sediments (DEPTH), and distance to the coast (DISTANCE). These five independent variables and their units were calculated in the following manner:

PERCENT = change in marsh area (ha) in a quadrangle between 1955/56 and 1978 divided by area (ha) of marsh in 1955/56.

DEVDENS = the area (ha) of urban and agricultural devlopment combined (1978), divided by area (ha) of marsh in 1955/56.

CANDENS = the area (ha) of canals and spoils combined (1978) divided by area (ha) of marsh in 1955/56. SEDAGE $=$ estimated age (yrs) of sediments.

DEPTH $=$ depth $(m)$ of sediments.

DISTANCE $=$ distance $(\mathrm{m})$ to the coast.

All variables were standardized in a correlation matrix to prevent problems caused by different units of measurements. These variables are similar to those that Deegan and others (1984) used to model land loss (based on the original Wicker $(1980,1981)$ data), for the Mississippi River Deltaic Plain, and their initial analysis positively influenced this current study. However, their analysis was flawed. Although they determined that their predictive variables were not interdependent, their dependent variable representing marsh loss was calculated by subtraction (Marsh loss $=$ the area of marsh in 1955/56 (IMARSH) minus the area of marsh in 1978) from the predictive variable which accounted for the greatest amount of variability in their modeled data (that is, IMARSH). Consequently, 
Table 3. Factor score weights on principal components calculated by using an orthogonal transformation solution and varimax rotation.

The factors account for $77.2 \%$ of the variability $(p<0.0001)$ in the original data set. Factor loadings greater than 0.314 are considered significant.

\begin{tabular}{lrrr}
\hline Variable & Factor 1 & Factor 2 & Factor 3 \\
\hline Percent $^{\mathrm{a}}$ & 0.158 & 0.508 & 0.299 \\
Distance (m) $_{\text {Sediment age (yrs) }}$ & 0.041 & -0.206 & 0.648 \\
Depth (m) & -0.516 & -0.120 & -0.118 \\
Canal density (\%) & 0.486 & 0.035 & -0.148 \\
Development density (\%) & -0.148 & 0.590 & -0.127 \\
\hline
\end{tabular}

apercent $=$ marsh (ha) $1955-1978 \times 100$ divided by marsh (ha) 1955.

their data were multicolinear, and their conclusion that marsh loss in a quadrangle was biologically related to stability caused by resistance to erosion may be erroneous.

In this study, the dependent variable PERCENT, as well as other variables representing area in a habitat category in 1978 (e.g., DEVDENS, CANDENS) were first normalized to the area of marsh in 1955/56. Principal components analysis (PCA) was used to test for multicolinearity among variables (dependent and predictive) and to determine if they accounted for a significant portion of the variability in the original data set (StatVew 512 +, BrainPower, Inc.). Factor score weights were calculated by using an orthogonal transformation solution and varimax rotation (Muliak 1972). Scores greater than 0.314 were considered significant. The value of 0.314 is arbitary, but implies that at least $10 \%$ of the variance for any given variable is accounted for by the factor on which it loads. Variables identified as significant in the PCA were employed in regression analysis (StatView $512+$, BrainPower, Inc.) to quantitatively model their relationship to the percentage of marsh lost in a quadrangle map unit between 1955/56 nad 1978. As a final examination, the quadrangle map units were ordinated (clustered) by using a clustering procedure (PROC FASTCLUS; SAS Institute Inc. 1985), which uses the nearest centroid clustering algorithm, following Anderberg (1973).

\section{Results and Discussion}

\section{Prinicpal Components Analysis}

Results from prinicpal components analysis (PCA) indicate that the variables chosen to model marsh loss together account for a significant portion of the vari- ability in the original data $(77.2 \% ; p<0.0001)$ and that the variables are not interdependent. However, interpretation of the variable factor score weights (Table 3), along with the proportionate variance contributions of each factor $(0.395,0.310$, and 0.294 for factors $1-3$, respectively), suggest that the relationship among the variables is complex. No variable loaded highly on more than one factor and no factor accounted for a disproportionate amount of the variability. However, some patterns are evident and warrant discussion. The only variables to score highly on factor 1 were sediment age and sediment depth; these variables were inversely related to one another. The variables representing land loss and canal density loaded (PERCENT) highly on factor 2, while distance to the coast and developed area scored high on factor 3. The inverse relationship between sediment depth and age on factor 1 reflects that younger sediments apparently overlie the Pleistocene terrace more thickly than older ones. Consequently, these young sediments may be more susceptible to compaction and consolidation. The variable scores on factor 2 suggest a relationship between increased canal and spoil area in the coastal zone with increased marsh loss. Finally, the variable scores on factor 3 show that the area of development is related to distance, indicating that activities associated with urbanization and agriculture most frequently occur some distance away from the Louisiana coastline. The variable representing marsh loss also loaded highly (but not significantly) on factor 3 .

\section{Multiple Regression Analyses}

The results of the PCA suggest that each of the selected variables needs to be included in this linear model to quantify the potential causal influences of marsh loss. Consequently, multiple regression analysis was employed to develop the following relationship (Table 4A):

$$
\begin{aligned}
\text { PERCENT }= & 15.46+4.971 * \text { CANDENS } \\
& +0.648 * \text { DEVDENS } \\
& +0.216 * \text { DEPTH } \\
& -0.000995 * \text { SEDAGE }
\end{aligned}
$$

The relationship of percentage of marsh loss in a quadrangle map unit to the predictive variables was highly significant ( $p<0.0001, R^{2}=0.40$ ) (Table 4A). The precision of the model is in Figure 2, which is a plot of the modeled percentage of marsh loss based on equation 1 versus the observed percentage of marsh loss obtained empirically from the data. The regression analysis agress well with the PCA results, even though the variable representing distance to the coast (DISTANCE) was dropped from in the regression model because of lack of significance. 
Table 4. Analysis of regression summary values for a multiple regression model relating marsh loss to natural and man-induced causal influences.

A. All map units combined. B. The Mississippi River Deltaic Plain. C. The Chenier Plain.

\begin{tabular}{|c|c|c|c|c|c|}
\hline & Source & DF & $p>F$ & Estimate & $R^{2}$ \\
\hline \multicolumn{6}{|l|}{ A. All map units combined } \\
\hline & Model & 4 & $0.0001 * *$ & - & 0.40 \\
\hline & Error & 133 & & & \\
\hline & Total & 137 & & & \\
\hline & Intercept & - & - & 15.46 & \\
\hline & CANDENS & 1 & $0.0001 * *$ & 4.971 & \\
\hline & DEVDENS & 1 & $0.0001^{* *}$ & 0.648 & \\
\hline & DEPTH & 1 & $0.0003^{* * *}$ & 0.216 & \\
\hline & SEDAGE & 1 & $0.0368^{*}$ & -0.000995 & \\
\hline \multicolumn{6}{|c|}{ B. Mississippi River Deltaic Plain } \\
\hline & Model & 4 & $0.0001 * *$ & - & 0.46 \\
\hline & Error & 104 & & & \\
\hline & Total & 108 & & & \\
\hline & Intercept & - & - & 14.90 & \\
\hline & CANDENS & 1 & $0.0001 * *$ & 36.91 & \\
\hline & DEVDENS & 1 & $0.0451 *$ & 0.322 & \\
\hline & DEPTH & 1 & $0.0005^{* *}$ & 0.197 & \\
\hline & SEDAGE & l & $0.0459 *$ & -0.002253 & \\
\hline \multicolumn{6}{|l|}{ C. Chenier Plain } \\
\hline & Model & 3 & $0.0001^{* *}$ & - & 0.58 \\
\hline & Error & 25 & & & \\
\hline & Total & 28 & & & \\
\hline & Intercept & - & 一 & 6.31 & \\
\hline & CANDENS & 1 & $0.0001 * *$ & 4.70 & \\
\hline & DEVDENS & 1 & $0.0143^{*}$ & 104.42 & \\
\hline & DEPTH & 1 & 0.5618 (NS) & 0.576 & \\
\hline
\end{tabular}

*Statistically significant $(\phi<0.05)$

**Highly significant $(p<0.01)$

NS $=$ Not significant

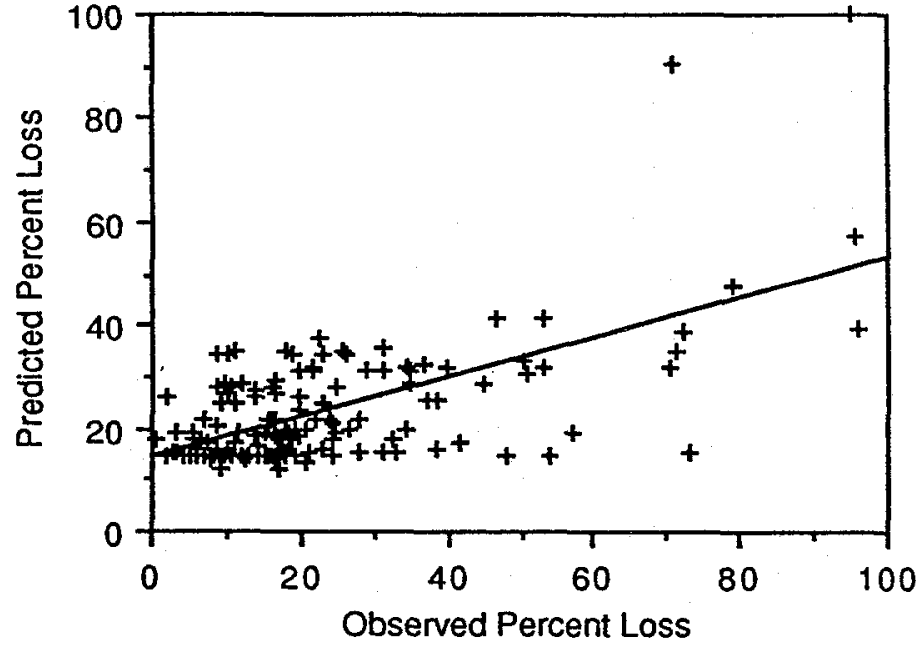

Figure 2. Predicted percentage of marsh loss versus observed percentage of marsh loss based on the results of the regression model given in equation 1 .
Although the regression relationship was significant, the variability in the original data explained by this linear model was relatively low $\left(R^{2}=0.40\right)$. Consequently, care must be exercised when attempting to predict or back calculate land loss (PERCENT) in any given map unit in this data set; the model is particularly poor when land loss rates are high. As will be discussed later, this may be a consequence of attempting to build a model to predict regional land loss for an area where local conditions differ enough 
across the region to necessitate a more localized approach, rather than our failure to include variables representing important potential causes.

Nevertheless, the variable representing canal and spoil area (CANDENS) was highly significant $(\phi<$ 0.0001 ) and accounted for the greatest amount of marsh loss. The positive regression coefficient $(+4.971)$ indicates that quadrangles with high canal density exhibited greater percentage of marsh loss from 1955/56 to 1978 than quadrangles with lower canal density. Canal and spoil impacts have been implicated in Louisiana wetland loss by several studies (Scaife and others 1983, Turner 1985, Walker and others 1987).

The area of development (DEVDENS) was also highly significant $(p<0.0001)$ in this linear model; nearly $65 \%$ of the increase in urbanized and agricultural area occurred at the expense (positive regression coefficient $=+0.648$ ) of coastal marshes. These results support the PCA, which suggests an inverse relationship between development and proximity to the Louisiana coast. Historical data show that urban and agriculture development in the Louisiana coastal zone first occurred on upland levee ridges inland from the coast. Recently, development has occurred in adjacent marshes (e.g., urban expansion and impoundment for agriculture) because much of the suitable uplands have already been developed (Deegan and others 1984).

The most important geologic variable related to marsh loss is the depth of sediment which overlies the down-warped Pleistocene terrace. The variable representing sediment depth (DEPTH) is highly significant $(\phi<0.0003)$, and the positive regression coefficient $(+0.216)$ indicates that percent marsh loss is greater in quadrangles with greater sediment depth. Sediment compaction, dewatering, and the resulting subsidence is greater as the depth of sediment increases (Fisk and McFarlan 1955). Since this and a previous attempt to quantitatively model land loss in Louisiana (Deegan and others 1984) show no significant relationship between distance from the coast and marsh loss, the empirical relationships between distance and sediment compaction (Kolb and Van Lopik 1958, Scaife and others 1983) and distance and land loss may be caused instead by sediment depth.

The last variable to enter the regression model $(p<$ 0.0368 ) was the geologic variable representing the age of underlying sediments (SEDAGE). A negative regression coefficient $(-0.000995)$ indicates an inverse relationship between the percentage of marsh loss in a quadrangle with the age of underlying sediments. Compaction and dewatering rates of deltaic sediments depend on several factors, including the age in years of the delta lobe in which the sediments were deposited (Walker and others 1987); that is, subsidence caused by compaction decreases with sediment age. Consequently, marsh loss is apparently higher in areas overlying more recently deposited sediments.

We previously suggested that the regression model's lack of precision and low $R^{2}$ were a consequence of trying to predict land loss on a regional scale for a highly variable ecosystem (that is, the Louisiana coastal zone) rather than a consequence of excluding variables representing other important potential causal factors. In order to illustrate this point, we subdivided the Louisiana coastal zone into several smaller units, based on either geology (e.g., Mississippi River Deltaic Plain (MRDP) versus Chenier Plain (CP)) or hydrologic unit (9 units; Figure 3). In each case, the subdividend was analyzed by using the linear regression model employed for the whole coastal zone. The results of the analyses for the MRDP and $\mathrm{CP}$ are in Table $4 \mathrm{~B}$ and $4 \mathrm{C}$, respectively. In both cases the regression model was highly significant and the $R^{2} \mathrm{im}$ proved over the original analysis. However, the variable representing sediment age was not included in the CP model since it was singular for all quadrangles (that is, no variance). The models show several noteworthy differences in the regression coefficients. For example, in the MRDP model the coefficient for canal density was seven times higher $(+36.91)$ than in the original model $(+4.971)$. This suggests that canal and spoil indirect impacts in the MRDP are high relative to the whole coastal zone. The regression coefficient for sediment age was also larger in the MRDP model, compared with the original analysis $(-0.002253$ versus -0.000995 , respectively); in this case, differences were an order of magnitude. This reflects the relative importance of local geology (e.g., chronology of delta lobe deposition) to land loss in the MRDP. In the CP model, the variables representing both canal density and developed area were highly significant. However, the magnitude of the regression coefficients indicates that the area of urban and agricultural development is important in the CP, compared with the probable role of canals in land loss $(+104.42$ for DEVDENS vs +4.70 for CANDENS). The area of marsh that is impounded or semi-impounded for agricultural, urbanization, or other purposes in the $\mathrm{CP}$ is large (17-20\% of total area; Cowan and others 1988, for review) compared to the whole coast or the MRDP $(<10 \%)$. The impounding of coastal marshes has been implicated in increasing land loss rates within and adjacent to the impounded areas through direct conversion of marsh to upland (agriculture, urban) habitat, and effects on local hydrology (Cowan and others 1988), rather than the desired effect of reducing land 


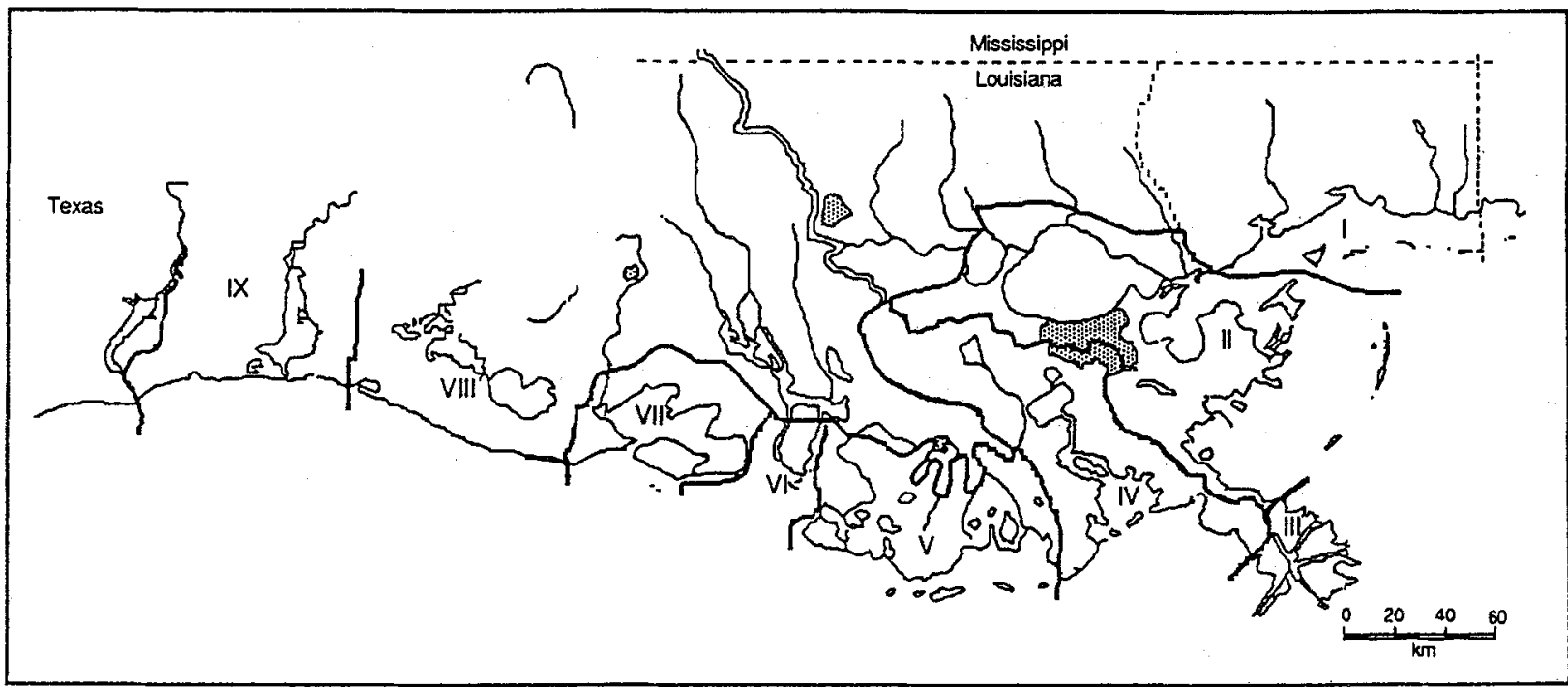

Figure 3. Location of the 9 hydrologic units within the study area. Note that Hydrologic Unit III includes that portion of the Mississippi River between crests of the east and west bank flood protection levees, and that the coastal boundary in Mississippi follows the $5 \mathrm{~m}$ contour line and is only drawn approximately on this map (adapted from Wicker 1980).

Table 5. Analysis of regression summary values for a multiple regression model relating marsh loss to natural and man-induced causal influences in selected hydrologic units of the Louisiana coastal zone.

Degrees of freedom for model $=4$.

\begin{tabular}{|c|c|c|c|c|c|}
\hline & Source & $\mathrm{DF}$ & $p>\mathrm{F}$ & Estimate & $R^{2}$ \\
\hline \multicolumn{6}{|l|}{ A. Pontchartrain (HU II) } \\
\hline & Total & 34 & $0.0001 * *$ & 一 & 0.78 \\
\hline & Intercept & - & - & 17.953 & \\
\hline & CANDENS & 1 & $0.0001 * *$ & 139.179 & \\
\hline & DEVDENS & 1 & $0.0012 * *$ & -0.942 & \\
\hline & SEDAGE & 1 & 0.3585 (NS) & -0.001406 & \\
\hline & DEPTH & 1 & 0.9864 (NS) & -0.002038 & \\
\hline \multicolumn{6}{|l|}{ B. Barataria (HU IV) } \\
\hline & Total & 23 & $0.0003 * *$ & - & 0.58 \\
\hline & Intercept & - & - & 2.512 & \\
\hline & CANDENS & 1 & 0.1105 (NS) & 29.653 & \\
\hline & DEVDENS & 1 & 0.5821 (NS) & 2.505 & \\
\hline & SEDAGE & 1 & 0.327 (NS) & -0.001775 & \\
\hline & DEPTH & 1 & $0.0006^{* *}$ & 0.377 & \\
\hline \multicolumn{6}{|l|}{ C. Terrebonne (HU V) } \\
\hline & Total & 31 & $0.0055^{* *}$ & - & 0.32 \\
\hline & Intercept & & - & 0.996 & \\
\hline & CANDENS & 1 & $0.0139 *$ & 54.419 & \\
\hline & DEVDENS & 1 & 0.2298 (NS) & -15.908 & \\
\hline & SEDAGE & 1 & 0.3729 (NS) & -0.0004336 & \\
\hline & DEPTH & 1 & $0.0465^{*}$ & 0.383 & \\
\hline \multicolumn{6}{|c|}{$\begin{array}{l}\text { D. Atchafalaya and Vermilion } \\
\text { (HU VI and VII) }\end{array}$} \\
\hline & Total & 17 & 0.4047 (NS) & - & 0.02 \\
\hline & Intercept & - & - & 20.969 & \\
\hline & CANDENS & 1 & 0.6683 (NS) & 5.447 & \\
\hline & DEVDENS & 1 & 0.4799 (NS) & 4.92 & \\
\hline & SEDAGE & 1 & 0.2912 (NS) & -0.0002339 & \\
\hline & DEPTH & 1 & 0.5438 (NS) & -0.085 & \\
\hline
\end{tabular}

*Statistically significant $(\mathrm{P}<0.05)$

**Highly significant $(\mathrm{P}<0.01)$

NS $=$ Not significant 
Table 6. Summary data from a cluster analysis performed to ordinate the quadrangle map units based on land loss rate (PERCENT) and the predictive variables from the multiple regression analyses.

The number of quadrangles in each ciuster is in parentheses.

\begin{tabular}{lccr}
\hline & & Frequency and cluster means & Cluster 3(55) \\
\cline { 2 - 4 } Variable & Cluster 1 (47) & Cluster 2 (64) & 20.00 \\
PERCENT & 22.00 & 36.00 & 2.25 \\
CANDENS & 0.60 & 0.11 & 2.42 \\
DEVDENS & 1.90 & 0.17 & 4124.02 \\
SEDAGE & 2144.91 & 516.36 & 16.40 \\
DEPTH & 27.43 & 67.98 & 10 \\
\hline
\end{tabular}

loss in the managed area. These regression data bolster this implication, even though we do not suggest that the analysis quantifies the relationship between land loss and impoundment effects in the CP.

The subdividends of the whole coast based on hydrologic unit (HU) were, again, analyzed with the linear model described earlier. The results (Table 5) provide insight into the behavior of the potential causal factos of land loss in Louisiana in more specific areas along the coast. For example, the magnitude of the significant regression coefficients in the model for HU II (Pontchartrain) (Table 5A) suggests that the density of canals and spoil is highly $(+)$ correlated with land loss in that area, relative to the other potential causal factors.

Scaife and others (1983) suggested a similar relationship between canals and land loss, based on data obtained from selected quadrangles in HU II. However, the regression coefficients from the HU IV (Barataria) model (Table 5B) show that the geologic variable representing sediment depth is important to account for the land loss in a quadrangle from that region. The regression coefficients from the models for HU IV (Terrebonne) and HUs VI and VII (Atchafalaya and Vermilion; Table $4 \mathrm{C}$ and $4 \mathrm{D}$, respectively) also show important differences. Interpretation of the regression coefficients from these combined analyses implies that the most important factors affecting land loss rates in the Louisiana coastal zone vary depending on location and geologic history, and that the coastal zone is not homogeneous with respect to the potential causal factors or their magnitude. This is not to say, however, that these analyses indicate that any of the causal factors represented by variables included in this linear model do not account for, or contribute to, land loss in the whole coastal zone to some degree because they lack statistical significance. Rather, we believe that the factors influencing land loss are locally variable and complex. More data are needed, perhaps from different sources (e.g., soil types, salinities, sedimentation rates) to precisely quan- tify and model the factors influencing marsh loss, particularly in areas where this linear model does not perform well (e.g., HUs VI and VII).

\section{Cluster Analysis and Ordination}

The combined results from the regression analyses (Tables 4 and 5) imply that considerable local variability exists in the modeled relationships between percentage of marsh loss in a quadrangle and the factors (predictive variables) that influence that loss. Therefore, we clustered (ordinated) our land loss data to identify quadrangles (areas) along the coast which are similar, that is, more or less susceptible to land loss, with respect to both land loss rates (PERCENT) and the predictive variables from the regression model. The cluster analysis (CA) created three clusters around the mean values that are shown in Table 6 following ten iterations of the original data. The quadrangle map units were then ordinated and placed in one of the clusters on the basis of their nearest centroid distance from the cluster mean for each variable. The results of the ordination (Figure 4) agree well with the combined interpretations of the regression analyses (Tables 4 and 5) and suggest that the Louisiana coastal zone is comprised of several distinct areas relative to land loss and its apparent causes. Cluster 1 is indicative of relativley high canal density and developed area in wetlands which overlie sediments of moderate depth and age. Percentage of land loss was also moderate in cluster 1 (Table 6). Many of the quadrangles in HUs II (Pontchartrain) and IV (Barataria) were placed in Cluster 1, which illustrates the complexity of the relationship between land loss and the predictive variables. In $\mathrm{HU}$ II, the regression analysis results (Table $5 \mathrm{~A}$ ) suggest that canal density and developed area were important factors which correlated with land loss, while sediment depth is most important in HU IV (Table 5B). These data at first seem to contradict the CA; however, when the magnitude, sign, and significance of each regression coefficient (including the intercepts) for each model are compared, 


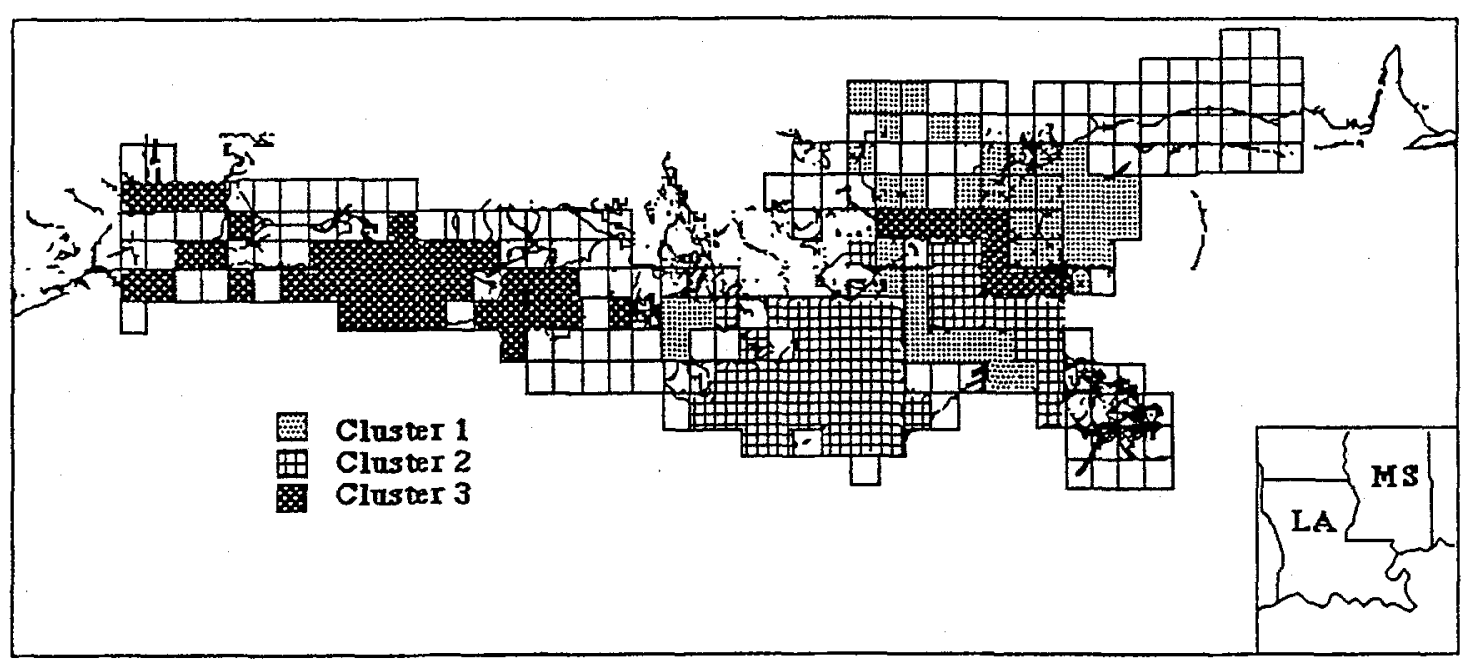

Figure 4. Regions of the Louisiana coastal zone determined from the cluster analysis.

the two analyses agree and aid in interpreting of the CA. In HU II, relatively high canal density has reportedly encouraged (positive regression coefficient = +139.179 ) moderate to high land loss (intercept $=$ 17.953), while in HU IV. lower canal density, combined with the moderating effects of older and more thinly deposited sediments, keeps land loss rates lower (intercept $=+2.512$ ). Interpretation of these combined data suggests that the indirect effects of canal density and development in quadrangles ordinated in cluster $\mathrm{I}$ are lessened by the geology of the area and land loss is moderated. On the other hand, the apparent effect of canal density and development on land loss in the quadrangles that ordinated with cluster 2 are higher. The cluster mean for PERCENT is highest in cluster 2 while the means for the other variables, including sediment age, were low; the mean of sediment depth was highest for cluster 2. Consequently, it appears that the potential for rapid land loss in the quadrangles of cluster 2 increases dramatically with an increase in man-induced activity (e.g., canals, spoil banks, and development); that is, local geology makes the area sensitive. Conversely, land loss in quadrangles in cluster 3 (Figure 4) is least influenced by canal density and development because of local geology (old and thin sediments), even though those quadrangles have experienced significant habitat alteration (that is, cluster means for CANDENS and DEVDENS are highest) and subsequent land loss.

\section{Summary and Conclusions}

Interpretation of the combined results from three quantitative analyses (principal components analysis, multiple regression analysis, and cluster analysis) suggests the following conclusions:
1. The complex and regional differences in land loss rates in the Louisiana coastal zone reflect variations in geology and the delta cycle (sediment age and deposition depth over the Pleistocene terrace), maninduced changes in hydrology (principally canal dredging and spoil banking), and land-use changes (principally urbanization and agricultural expansion). Interpretation of the results of principal components and regression analyses suggests that the most important factors (represented here by the predictive variables) that are correlated with changes in land loss rates vary depending on location and geologic history, and that the coastal zone is not homogeneous with respect to causal factors or their magnitude. These analyses also indicate that each of the causal factors represented by variables included in this study probably contribute to land loss in the whole coastal zone to some degree and that their interaction between causal factors is locally variable and complex.

2. The relationship between land loss, hydrologic changes, and geology can be described with statistically meaningful results, even though these data are insufficient to precisely quantify the relationship. However, these data support the hypothesis that the indirect impacts of man-induced changes (hydrologic and land use) may be as influential as the direct impacts of converting wetlands to open water (canals) or modified (impounded) habitat (Turner 1985). For example, the mean land loss in all quadrangles used in this analysis was $23.5 \%$. By interpolating with the regression coefficients obtained from this analysis, a $50 \%$ reduction in canal density would result in a nearly $10 \%$ decrease in land loss $(x=21.5 \%)$, while the direct impacts of canal and spoil account for only $8.0 \%(\approx 23,000$ of 288,414 ha) of the marsh loss (at zero canal density, land loss is reduced by $10.3 \%$; Table 7 ). If the direct impacts of 
Table 7. Estimates of wetland loss, by region, at zero canal and spoil density, based on interpolation in the regression equations obtained in Tables 5 and 6.

Care must be exercised, however, when interpreting the results of back-calculation.

\begin{tabular}{lcccc}
\hline & \multicolumn{3}{c}{ Wetland loss (\%) } \\
\cline { 2 - 5 } Spatial Unit & Model $R^{2}$ & $\begin{array}{c}\text { Currently } \\
1955 / 6-1978\end{array}$ & $\begin{array}{c}\text { Zero canal } \\
\text { and spoil }\end{array}$ & Reduction \\
\hline Louisiana coastal zone & 0.40 & 23.5 & 21.1 & 10.3 \\
Deltaic plain & 0.46 & 23.9 & 20.2 & 15.3 \\
Chenier plain & 0.58 & 22.2 & 13.0 & 5.8 \\
HU II & 0.78 & 23.7 & 24.1 & 4.3 \\
HU IV & 0.58 & 25.0 & not calculated \\
HU V & 0.32 & & not calculated \\
HU VI and VII & 0.02 & &
\end{tabular}

canal, spoil, and development are eliminated by interpolation, marsh loss is reduced by nearly $20 \%$ while their direct impacts account for only $15 \%$ of that loss. These back-calculations are based on interpolation, however, and care must be exercised during interpretation of results.

3. Three regions within the Louisiana coastal zone can be defined, based on the potential causal factors used in the cluster analysis. The moderate (mean = $22 \%$ ) wetland loss rates in region 1 are a result of relatively high canal density and developed area in marshes which overlie sediments of moderate age and depth; local geology acts, in this case, to lessen indirect impacts. On the other hand, land loss rates in region 2 are high (mean $=36 \%$ ), despite fewer man-induced impacts; the potential for increased land loss due to both direct and indirect effects of man's activity in these areas is high. Conversely, land loss (mean = $20 \%$ ) in region 3 is apparently least influenced by man's activity in the coastal zone because of sedimentary geology (old, thin sediments), even though these areas have experienced significant direct habitat alteration and land loss.

\section{Acknowledgments}

This work was supported by a contract with the Minerals Management Service, US Department of Interior. Ms. Jami Donley helped prepare the manuscript, which benefits from the critical reviews of $S$. Leibowitz and D. Cahoon.

\section{Literature Cited}

American Petroleum Institute. 1981. Basic petroleum data book, vol. 1(3). Washington, DC.

Anderberg, M. R. 1973. Cluster analysis for applications. Academic Press, New York. 359 pp.

Cahoon, D. R. and J. H. Cowan, Jr. 1987. Spray disposal of dredged material in Louisiana wetlands: habitat impacts and regulatory policy implications. Final report, Louisiana Sea Grant Project No. RMPE-37-PD, Louisiana State University, Baton Rouge. 37 pp.

Cahoon, D. R. J. Donley, S. Hamilton, and R. E. Turner. 1986. Prototype handbook for evaluating drilling site access in wetlands via canals. Report to Lee Wilson, Associates, Inc. Santa Fe, New Mexico.

Chabreck, R. H. 1979. Wildlife harvest in wetlands of the United States. Pages 618-631 in P. E. Greeson, J. R. Clark, and J. E. Clark (eds.), Wetland functions and values: the state of our understanding. American Water Resources Association, Minneapolis, MN. 674 pp.

Costanza, R., C. Neill, S. G. Leibowitz, J. R. Fruci, L. M. Bahr, Jr., and J. W. Day, Jr. 1983. Ecological models of the Mississippi deltaic plain region: data collection and presentation. US Fish and Wildlife Service, Office of Biological Services, FWS/OBS-82/68. Washington, DC 342 pp.

Cowan, J. H., Jr., R. E. Turner, and D. R. Cahoon. 1988. Marsh management plans in practice: do they work in coastal Louisiana, USA? Environmental Management 12:3755.

Cowardin, L. M., V. Carter, F. C. Golet, and E. T. LaRoe. 1979. Classification of wetlands and deepwater habitats of the United States. US Fish and Wildlife Service, FWS/OBS79/31. Washington, DC. $103 \mathrm{pp}$.

Craig, N. J., R. E. Turner, and J. W. Day, Jr. 1980. Wetlands losses and their consequences in coastal Louisiana. Zeitshrift Geomorphologie. N.F. 34:225-241.

Davis, D. W. 1973. Louisiana canals and their influence on wetland development. Ph.D. dissertation, Louisiana State University, Baton Rouge, LA. 199 pp.

Day, J. W., Jr., R. Costanza, K. Teague, N. Taylor, R. H. Day, and R. E. Becker. 1986. Wetland impoundment: a global survey for comparison with the Louisiana coastal zone. Final report to the Geological Survey Division, Louisiana Department of Natural Resources. 140 pp.

Deegan, L. A., H. M. Kennedy, and C. Neill. 1984. Natural factors and human modifications contributing to marsh loss in Louisiana's Mississippi River deltaic plain. Environmental Management 8(6):519-528.

Fisk, H. N., and E. McFarlan, Jr. 1955. Late Quartenary deltaic deposits of the Mississippi. Pages 279-302 in A. Poldervaart (ed.), Crust of the earth. Geological Society of America, Special Paper 62. 
Frazier, D. E. 1967. Recent deltaic depostis of the Mississippi River, their development and chronology. Transactions of the Gulf Coast Association Geologists Society 17:287-315.

Gagliano, S. M. 1973. Canals, dredging and land reclamation in the Louisiana coastal zone. Hydrologic and geologic studies, Report 14. Center for Wetland Resources, Louisiana State University, Baton Rouge. 104 pp.

Gagliano, S. M., K. J. Meyer-Arendt, and K. M. Wicker. 1981. Land loss in the Mississippi river deltaic plain. Transactions of the Gulf Coast Association Geologists Society 31:295300.

Gosselink, J. G., C. L. Cordes, and J. W. Parsons. 1979. An ecological characterization study of the Chenier plain coastal ecosystem of Louisiana and Texas. Vol. 2. Appendices. US Fish and Wildlife Service, Office of Biological Services, FWS/OBS-78/10. Washington, DC. 407 pp.

Kolb, C. R., and J. R. Van Lopik. 1958. Geology of the Mississippi River deltaic plain, Southeastern Louisiana. US Army Corps of Engineers, Waterways Experiment Station, Vicksburg, MS. 'Technical Report No. 3-483. Vol. 1. 120 pp.

Kosters, E. C., G. L. Chmura, and A. Bailey. 1987. Sedimentary and botanical factors influencing peat accumulation in the Mississippi delta. Joumal of the Geological Society London 144:423-434.

Lindstedt, D. M., and L. Nunn. 1985. Petroleum development in Louisiana's coastal zone. In O. T. Magoon, D. Miner, D. Clark, and L. T. Tobin (eds.), Coastal zone ' 85. Vol. 2, Proceedings of the fourth symposium on coastal and ocean management, New Orleans, LA.

Mager, A., Jr., and L. H. Hardy. 1986. National marine fisheries service habitat conservation efforts in the southeastern region of the United States for 1985. NMFS, Conservation Division, St. Petersburg, FL.

Meade, R. H., and R. S. Parker. 1984. Sediments in rivers of the United States. National Water Supply Summary. US Geological Survey Water-Supply Paper 2275, Vicksburg, MS.

Morgan, J. P. 1963. Louisiana's changing shoreline. United States Gulf Coastal Studies Technical Report 16, part D 65-5. Coastal Studies Institute, Louisiana State University, Baton Rouge. 13 pp.

Muliak, S. A. 1972. The foundations of factor analysis. McGraw-Hill Book Co., New York.
SAS Institute, Inc. 1985. SAS user's guide: statistics, version 5 edition. SAS Institute Inc., Carry, NC. 956 pp.

Scaife, W. B., R. E. Turner, and R. Costanza. 1983. Recent land loss and canal impacts in coastal Louisiana. Environmental Management 7(5):433-442.

Swenson, E. M., and R. E. Turner. 1987. Spoil banks: effects on coastal marsh water level regime. Estuarine, Coastal and Shelf Science 24:599-609.

Turner, R. E. 1985. Coastal land loss, canals and canal levee relations in Louisiana. US Fish and Wildlife Service, Office of Biological Services, FWS/OBS-85/14.

Turner, R. E., R. Costanza, and W. Scaife. 1982. Canals and land loss in coastal Louisiana. Pages 73-84 in D. F. Boesch (ed.), Proceedings of the conference on coastal erosion and wetland modification in Louisiana: causes, consequences and options. US Fish and Wildlife Service, Biological Services Program, FWS/OBS-82/59. Washington, DC. 256 pp.

Turner, R. E., and J. G. Gosselink. 1975. A note on standing crop of Spartina alterniflora in Texas and Florida. Contributions in Marine Science 19:13-18.

US Department of Commerce. 1987. Fisheries of the United States. 1986. Current fishery statistics no. 8206. National Marine Fisheries Service, National Oceanic and Atmospheric Administration, Washington, DC.

US Department of the Interior, Fish and Wildlife Service and US Department of Commerce, Bureau of the Census. 1982. 1980 National survey of fishing, hunting and wildlife related recreation. US Government Printing Office, Washington, DC.

Walker, H. J., J. M. Coleman, H. H. Roberts, and R. S. Tye. 1987. Wetland loss in Louisiana. Geografiska Annaler $69 \mathrm{~A}(1): 189-200$.

Wicker, K. M. 1980. Mississippi deltaic plain region ecological characterization: a habitat mapping study. A user's guide to the habitat maps. US Fish and Wildlife Service, Office of Biological Services, FWS/OBS-79/07. Slidell, Louisiana.

Wicker, K. M. 1981. Chenier plain region ecological characterization: a habitat mapping study (A user's guide to the habitat maps). Louisiana Coastal Resources Program, Loujsiana Department of Natural Resources, Baton Rouge, LA. 